\title{
ARHGAP26 wt Allele
}

National Cancer Institute

\section{Source}

National Cancer Institute. ARHGAP26 wt Allele. NCI Thesaurus. Code C97505.

Human ARH GAP26 wild-type allele is located in the vicinity of $5 q 31$ and is approximately $459 \mathrm{~kb}$ in length. This allele, which encodes Rho GT Pase-activating protein 26, is involved in the modulation of signaling by both transforming protein RhoA and cell division control protein 42 homolog. Both mutation of the gene and a chromosomal translocation $t(5 ; 11)(q 31 ; q 23)$ of this gene and the MLL gene are associated with juvenile myelomonocytic leukemia. 